\title{
Pyridine Derivatives-A New Class of Compounds That Are Toxic to E. coli K12, R2-R4 Strains
}

\author{
Dominik Koszelewski ${ }^{1}$, Ryszard Ostaszewski ${ }^{1}$, Paweł Śmigielski ${ }^{1}$, Anastasiia Hrunyk ${ }^{1}$, Karol Kramkowski ${ }^{2}$,

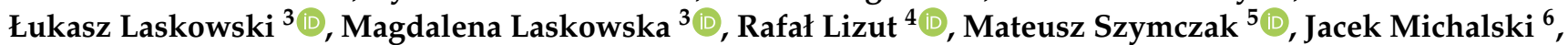 \\ Kamil Gawin ${ }^{6}$ and Paweł Kowalczyk ${ }^{6, *(1)}$
}

Citation: Koszelewski, D.; Ostaszewski, R.; Śmigielski, P.; Hrunyk, A.; Kramkowski, K.; Laskowski, Ł.; Laskowska, M.; Lizut, R.; Szymczak, M.; Michalski, J.; et al. Pyridine Derivatives-A New Class of Compounds That Are Toxic to E. coli K12, R2-R4 Strains. Materials 2021, 14, 5401. https://doi.org/ $10.3390 /$ ma14185401

Academic Editors: Jordi Marti and Abdelwahab Omri

Received: 17 July 2021

Accepted: 16 September 2021

Published: 18 September 2021

Publisher's Note: MDPI stays neutral with regard to jurisdictional claims in published maps and institutional affiliations.

Copyright: () 2021 by the authors Licensee MDPI, Basel, Switzerland. This article is an open access article distributed under the terms and conditions of the Creative Commons Attribution (CC BY) license (https:/ / creativecommons.org/licenses/by/ $4.0 /)$.
1 Institute of Organic Chemistry PAS, Kasprzaka 44/52, 01-224 Warsaw, Poland; d.koszelewski@icho.edu.pl (D.K.); r.ostaszewski@icho.edu.pl (R.O.); p.smigielski@icho.edu.pl (P.Ś.); a.hrunyk@icho.edu.pl (A.H.)

2 Department of Physical Chemistry, Medical University of Bialystok, Kilińskiego 1 Str., 15-089 Białystok, Poland; kkramk@wp.pl

3 Institute of Nuclear Physics Polish Academy of Sciences, 31-342 Krakow, Poland; lukasz.laskowski@ifj.edu.pl (Ł.L.); magdalena.laskowska@ifj.edu.pl (M.L.)

4 The John Paul II Catholic University of Lublin, Institute of Mathematics, Informatics and Landscape Architecture ul. Konstantynów 1 H, 20-708 Lublin, Poland; lizut@kul.pl

5 Department of Molecular Virology, Institute of Microbiology, Faculty of Biology, University of Warsaw, Miecznikowa 1, 02-096 Warsaw, Poland; mszymczak@biol.uw.edu.pl

6 Department of Animal Nutrition, The Kielanowski Institute of Animal Physiology and Nutrition, Polish Academy of Sciences, 05-110 Jabłonna, Poland; j.michalski@ifzz.pl (J.M.); k.gawin@ifzz.pl (K.G.)

* Correspondence: p.kowalczyk@ifzz.pl

Abstract: A preliminary study of 2-amino-4-aryl-3,5-dicarbonitrile-6-thiopyridines as new potential antimicrobial drugs was performed. Special emphasis was placed on the selection of the structure of target pyridine derivatives with the highest biological activity against different types of Gram-stained bacteria by lipopolysaccharide (LPS). Herein, Escherichia coli model strains K12 (without LPS in its structure) and R2-R4 (with different lengths of LPS in its structure) were used. Studied target compounds were provided with yields ranging from $53 \%$ to $91 \%$ by the lipase-catalyzed one pot multicomponent reaction of various aromatic aldehydes with malononitrile, and thiols. The presented work showed that the antibacterial activity of the studied pyridines depends on their structure and affects the LPS of bacteria. Moreover, the influence of the pyridines on bacteria possessing smooth and rough LPS and oxidative damage to plasmid DNA caused by investigated compounds was indicated. Additionally, the modification of the bacterial DNA with the tested compounds was performed to detect new potential oxidative damages, which are recognized by the Fpg protein. The obtained damage modification values of the analyzed compounds were compared with the modifications after antibiotics were used in this type of research. The presented studies demonstrate that 2-amino-4-aryl-3,5-dicarbonitrile-6-thiopyridines can be used as substitutes for known antibiotics. The observed results are especially important in the case of the increasing resistance of bacteria to various drugs and antibiotics.

Keywords: pyridine derivatives; E. coli strains; oxidative stress; antibiotics; lipopolysaccharide

\section{Introduction}

The pyridine ring system can be found in a number of natural products and in several pharmacologically relevant compounds. Among others, 2-amino-4-aryl-3,5-dicarbonitrile6-thiopyridines have gained considerable attention due to their wide-ranging biological activities (Figure 1) [1]. 


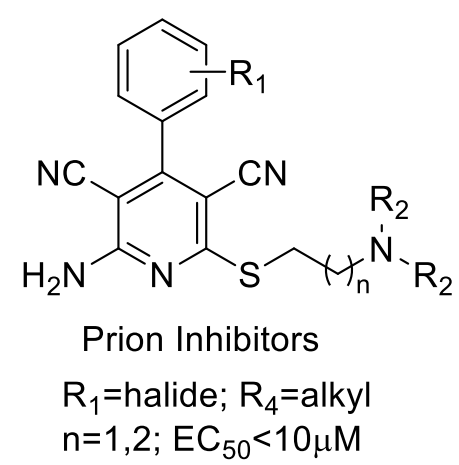
$\mathrm{n}=1,2 ; \mathrm{EC}_{50}<10 \mu \mathrm{M}$<smiles>N#Cc1c(N)nc(SCc2csc(-c3ccc(Cl)cc3)n2)c(C#N)c1-c1ccc(OCCO)cc1</smiles>

Agonist of adenosine- $\mathrm{A}_{1}$ receptor

Figure 1. The 2-amino-4-aryl-3,5-dicarbonitrile-6-sulfanylpyridines as medicinally privileged structures.

These pyridine derivatives were found to inhibit PrPSc accumulation in scrapieinfected mouse neuroblastoma cells (ScN2a) [2], act as an adenosine A1 receptor agonist for the chronic treatment of heart diseases [3,4] modulate androgen receptor function [5], and function as IKK-2 for treating HBV infection [6], Additionally, these compounds are often used as anti-prion [7,8], anti-hepatitis B virus [9], anti-bacterial [10], and anti-cancer [11] agents, and as potassium channel openers for the treatment of urinary incontinence [12] Recently, these compounds have been recognized as potential targets for the development of new drugs for the treatment of Alzheimer and neuronal vascular diseases, Parkinson's, hypoxia, asthma, kidney, epilepsy, and Creutzfeldt-Jacob diseases [13-16]. At present, there are insufficient data in the professional scientific literature on the cytotoxic properties of simple synthetic pyridine derivatives performed on Escherichia coli R1-R4 model bacterial cells. Investigating pyridine derivatives and their potentially toxic effect on bacterial cells may reveal them be helpful in many new cases of drug resistance (including antibiotics) as effective antimicrobials against bacterial clinical pathogens. The aim of the study is to analyze the potential antibacterial activity of 2-amino-4-aryl-3,5-dicarbonitrile-6sulfanylpyridines as potential antibiotics in terms of their structure and their cytotoxic effect on bacterial lipopolysaccharides (LPS) in the model strains used in this type of research on Escherichia coli K12 (without LPS in its structure) and R2-R4 (LPS of different lengths in its structure).

\section{Materials and Methods}

\subsection{General Methods of Synthesis Pyridine Derivatives}

All the chemicals were purchased from Sigma-Aldrich and the solvents were of analytical grade. Melting points of all the synthesized compounds were determined in open capillary tubes and are uncorrected. Toluene was distilled over $\mathrm{Na} / \mathrm{K}$-alloy in the presence of benzophenone. ${ }^{1} \mathrm{H}$ NMR spectra were recorded in $\mathrm{CDCl}_{3}$ or DMSO- $d_{6}$ solution using Varian Gemini $400 \mathrm{NMR}$ spectrometer $(400 \mathrm{MHz})$. MS spectra were reordered on API 3000 mass spectrometer (Applied Biosystems). TLC analyses were performed on Kieselgel $60 \mathrm{~F}_{254}$ aluminum sheets. TLC were developed in $\mathrm{KMnO}_{4}$ solution containing $\mathrm{K}_{2} \mathrm{CO}_{3}$ and $\mathrm{NaOH}$. Lipases from porcine pancreas, Type II (PPL) (catalogue number L-3126, Lot. Number 108H1379), Pseudomonas fluorescens (PFL) (catalogue number 534730, Lot. Number MKBH1198V), Candida rugosa (CRL) (catalogue number 90860, Lot. Number BCBH7102V), Candida cylindracea (CCL) (catalogue number 62316, Lot. Number 1336707), Burkholderia ÿepacian (BCL) (catalogue number 534641, Lot. Number MKBV0029V) and Rhizomucor miehei (RML) (catalogue number 80484) and Bovine serum albumin were purchased from Sigma-Aldrich. Immobilized lipase from Candida antarctica B (Novozym 435) (catalogue number LC200223) was purchased from Novo Nordisk. Enzymatic reactions were performed in a vortex (Heidolph Promax 1020) equipped with incubator (Heidolph Inkubator 1000). To prove the ability of the established protocol, each reaction was repeated at least three times. 
2.2. General Procedure for the Synthesis of 2-Amino-4-aryl-3,5-dicyano-6-phenyl Thiopyridines $(5 \mathbf{a}-\mathbf{k})$

A mixture of an aldehyde (1 mmol), PPL (100 mg), malononitrile $(2 \mathrm{mmol})$ and thiol $(1 \mathrm{mmol})$ in ethanol $(2 \mathrm{~mL})$ was shaken at $200 \mathrm{rpm}$ at $40{ }^{\circ} \mathrm{C}$ for $18 \mathrm{~h}$. Reaction was terminated by filtering off the catalyst through the bed of celite. The MCR toward 5a, catalyzed by different enzymes are recorded in Table 2 . The melting points and the yields of the derivatives are recorded in Table 1. Melting points and spectral data of $\mathbf{5 a - k}$ remained in agreement with the literature data. The structure of all compounds was confirmed using NMR and mass spectroscopy and, for some compound, the correct elemental analysis data were also recorded in each method synthesis.

Table 1. Yields of reaction provided for isolated products $5^{\mathrm{a}}$.

\begin{tabular}{|c|c|c|c|c|c|}
\hline Entry & Compound & $\mathbf{R}_{1}$ & $\mathbf{R}_{2}$ & Yield [\%] ${ }^{b}$ & $\operatorname{Mp}\left({ }^{\circ} \mathrm{C}\right)^{\mathrm{c}}$ \\
\hline 1 & $5 a$ & $4-\mathrm{CNC}_{6} \mathrm{H}_{4}$ & $4-\mathrm{MeC}_{6} \mathrm{H}_{4}$ & 83 & 275 \\
\hline 2 & $5 b$ & thiophene & $4-\mathrm{MeC}_{6} \mathrm{H}_{4}$ & 78 & 197 \\
\hline 3 & $5 c$ & $\mathrm{Ph}$ & $4-\mathrm{NH}_{2} \mathrm{C}_{6} \mathrm{H}_{4}$ & 53 & 223 \\
\hline 4 & $5 \mathrm{~d}$ & $\mathrm{Ph}$ & $4-\mathrm{MeC}_{6} \mathrm{H}_{4}$ & 89 & 249 \\
\hline 5 & $5 e$ & $\mathrm{Ph}$ & $n-\mathrm{C}_{6} \mathrm{H}_{13}$ & 76 & 148 \\
\hline 6 & $5 \mathrm{f}$ & 4- $\mathrm{MeC}_{6} \mathrm{H}_{4}$ & $4-\mathrm{MeC}_{6} \mathrm{H}_{4}$ & 91 & $223-224$ \\
\hline 7 & $5 g$ & $\mathrm{Ph}$ & $4-\mathrm{ClC}_{6} \mathrm{H}_{4}$ & 89 & 247 \\
\hline 8 & $5 \mathrm{~h}$ & $4-\mathrm{MeOC}_{6} \mathrm{H}_{4}$ & $4-\mathrm{MeC}_{6} \mathrm{H}_{4}$ & 82 & $230-231$ \\
\hline 9 & $5 \mathrm{i}$ & $4-\mathrm{NO}_{2} \mathrm{C}_{6} \mathrm{H}_{4}$ & $4-\mathrm{MeC}_{6} \mathrm{H}_{4}$ & 88 & 298 \\
\hline 10 & $5 j$ & $\mathrm{Ph}$ & $4-\mathrm{BrC}_{6} \mathrm{H}_{4}$ & 74 & $255-257$ \\
\hline 11 & $5 \mathrm{k}$ & $2-\mathrm{OHC}_{6} \mathrm{H}_{4}$ & $4-\mathrm{MeC}_{6} \mathrm{H}_{4}$ & 79 & 224 \\
\hline
\end{tabular}

a Reaction conditions: Aldehyde (1 mmol), malanonitrile (2 mmol), thiol (1 mmol), PPL (100 mg), ethanol (2 mL), stirred at $40{ }^{\circ} \mathrm{C}$ for $18 \mathrm{~h}$. ${ }^{\mathrm{b}}$ Yield of isolated product. ${ }^{\mathrm{c}}$ Melting points remain in agreement with those reported in the literature (see Supplementary Material).

2-Amino-4-(4-cyanophenyl)-6-(4-methylphenylsulfanyl)-3,5-pyridinedicarbonitrile (5a)<smiles>Cc1ccc(Sc2nc(N)c(C#N)c(-c3ccc(C#N)cc3)c2C)cc1</smiles>

Compound 5a obtained according to general method with $83 \%$ yield ( $305 \mathrm{mg}, 0.83 \mathrm{mmol}$ ) as white crystal, $\mathrm{mp} 275^{\circ} \mathrm{C}(\mathrm{MeOH})$ [Lit. mp $\left.272-274{ }^{\circ} \mathrm{C}, \mathrm{EtOH}\right] ;{ }^{1}{ }^{1}{ }^{1} \mathrm{H} \mathrm{NMR}(400 \mathrm{MHz}$, DMSO- $\left.d_{6}\right) \delta 8.06(\mathrm{~d}, J=8.4 \mathrm{~Hz}, 2 \mathrm{H}), 7.85(\mathrm{~s}, 2 \mathrm{H}), 7.77(\mathrm{~d}, J=8.4 \mathrm{~Hz}, 2 \mathrm{H}), 7.46(\mathrm{~d}, J=8.2 \mathrm{~Hz}$, $2 \mathrm{H}), 7.29(\mathrm{~d}, J=7.9 \mathrm{~Hz}, 2 \mathrm{H}), 2.35(\mathrm{~s}, 3 \mathrm{H}) .{ }^{1} \mathrm{H}$ NMR data were in accordance with those reported in the literature. ${ }^{[2]} \mathrm{LRMS} \mathrm{m} / \mathrm{z}$ (ESI) calc. for $\mathrm{C}_{21} \mathrm{H}_{13} \mathrm{~N}_{5} \mathrm{SNa}[\mathrm{M}+\mathrm{Na}]^{+}: 390.0$. Found: 390.0.

2-Amino-4-(thiophen-2-yl)-6-(4-methylphenylsulfanyl)-3,5-pyridinedicarbonitrile (5b)<smiles>Cc1ccc(Sc2nc(N)c(C#N)c(-c3cccs3)c2C#N)cc1</smiles>

Compound $5 \mathrm{~b}$ obtained according to general method with $78 \%$ yield $(271 \mathrm{mg}, 0.78 \mathrm{mmol})$ as yellow crystal, mp $197^{\circ} \mathrm{C}(\mathrm{MeOH})$ [Lit. mp 196-198 ${ }^{\circ} \mathrm{C}, \mathrm{MeOH}$ ]; ${ }^{[2]}{ }^{1} \mathrm{H} \mathrm{NMR}(400 \mathrm{MHz}$, DMSO- $\left.d_{6}\right) \delta 8.00-7.89(\mathrm{~m}, 1 \mathrm{H}), 7.77(\mathrm{~s}, 2 \mathrm{H}), 7.55(\mathrm{dd}, J=3.7,1.3 \mathrm{~Hz}, 1 \mathrm{H}), 7.45(\mathrm{~d}, J=8.1 \mathrm{~Hz}$, $2 \mathrm{H}), 7.36-7.23(\mathrm{~m}, 3 \mathrm{H}), 2.35(\mathrm{~s}, 3 \mathrm{H}) ;{ }^{1} \mathrm{H}$ NMR data were in accordance with those reported in the literature. ${ }^{[2]} \mathrm{LRMS} \mathrm{m} / \mathrm{z}$ (ESI) calc. for $\mathrm{C}_{18} \mathrm{H}_{13} \mathrm{~N}_{4} \mathrm{~S}_{2}[\mathrm{M}+\mathrm{H}]^{+}$: 349.0, Found: 349.0. 


\section{2-Amino-6-((4-aminophenyl)thio)-4-phenylpyridine-3,5-dicarbonitrile (5c)}<smiles>Cc1c(Sc2ccc(N)cc2)nc(N)c(C#N)c1-c1ccccc1</smiles>

Compound $5 \mathrm{c}$ obtained according to general method with $52 \%$ yield $(178 \mathrm{mg}, 0.52 \mathrm{mmol})$ as yellow crystal, mp $223{ }^{\circ} \mathrm{C}(\mathrm{EtOH})$ [Lit. mp $219-221^{\circ} \mathrm{C}$ ]; ${ }^{[3]}{ }^{1} \mathrm{H}$ NMR $\left(400 \mathrm{MHz}\right.$, DMSO- $\left.d_{6}\right)$ $\delta 7.67(\mathrm{~s}, 2 \mathrm{H}), 7.58-7.47(\mathrm{~m}, 5 \mathrm{H}), 7.17(\mathrm{~d}, J=8.6 \mathrm{~Hz}, 2 \mathrm{H}), 6.61(\mathrm{~d}, J=8.6 \mathrm{~Hz}, 2 \mathrm{H}), 5.56(\mathrm{~s}, 2 \mathrm{H})$. ${ }^{1} \mathrm{H}$ NMR data were in accordance with those reported in the literature. ${ }^{[3]}$ LRMS $\mathrm{m} / \mathrm{z}$ (ESI) calc. for $\mathrm{C}_{19} \mathrm{H}_{14} \mathrm{~N}_{5} \mathrm{~S}[\mathrm{M}+\mathrm{H}]^{+}$: 344.1, Found: 344.1.

2-Amino-4-phenyl-6-( $p$-tolylthio)pyridine-3,5-dicarbonitrile (5d)<smiles>Cc1ccc(Sc2nc(N)c(C#N)c(-c3ccccc3)c2C)cc1</smiles>

Compound $\mathbf{5 d}$ obtained according to general method with $89 \%$ yield ( $304 \mathrm{mg}, 0.89 \mathrm{mmol}$ ) as white crystal, mp $249{ }^{\circ} \mathrm{C}(\mathrm{EtOH})\left[\right.$ Lit. mp $\left.248-250{ }^{\circ} \mathrm{C}(\mathrm{EtOH})\right] ;{ }^{[4]}{ }^{1} \mathrm{H} \mathrm{NMR}(400 \mathrm{MHz}$, $\left.\mathrm{CDCl}_{3}\right) \delta 7.53$ (hept, $\left.J=3.5,3.0 \mathrm{~Hz}, 5 \mathrm{H}\right), 7.43(\mathrm{~d}, J=8.2 \mathrm{~Hz}, 2 \mathrm{H}), 7.27-7.21(\mathrm{~m}, 2 \mathrm{H}), 5.46$ $(\mathrm{s}, 2 \mathrm{H}), 2.42(\mathrm{~s}, 3 \mathrm{H}) .{ }^{1} \mathrm{H}$ NMR data were in accordance with those reported in the literature.

${ }^{[5]}$ LRMS m/z (ESI) calc. for $\mathrm{C}_{20} \mathrm{H}_{15} \mathrm{~N}_{4} \mathrm{~S}[\mathrm{M}+\mathrm{H}]^{+}: 343.0$, Found: 343.0.

2-Amino-6-(octylthio)-4-phenylpyridine-3,5-dicarbonitrile (5e)<smiles>CCCCCCCCSc1nc(N)c(C#N)c(-c2ccccc2)c1C#N</smiles>

Compound 5e obtained according to general method with $76 \%$ yield $(277 \mathrm{mg}, 0.76 \mathrm{mmol})$ as white crystal, $\mathrm{mp} 148{ }^{\circ} \mathrm{C}(\mathrm{EtOH})$ [Lit. mp $\left.151-153{ }^{\circ} \mathrm{C}(\mathrm{EtOH})\right] ;{ }^{[6]}{ }^{1} \mathrm{H} \mathrm{NMR}(400 \mathrm{MHz}$, $\left.\mathrm{CDCl}_{3}\right) \delta 7.73-7.37(\mathrm{~m}, 5 \mathrm{H}), 5.63(\mathrm{~s}, 2 \mathrm{H}), 3.20(\mathrm{t}, J=7.3 \mathrm{~Hz}, 2 \mathrm{H}), 1.73(\mathrm{t}, J=7.5 \mathrm{~Hz}, 2 \mathrm{H})$, $1.45(\mathrm{t}, J=7.5 \mathrm{~Hz}, 2 \mathrm{H}), 1.40-1.21(\mathrm{~m}, 8 \mathrm{H}), 0.89(\mathrm{t}, J=7.5 \mathrm{~Hz}, 3 \mathrm{H}) .{ }^{1} \mathrm{H}$ NMR data were in accordance with those reported in the literature. ${ }^{[6]}$ LRMS $\mathrm{m} / \mathrm{z}$ (ESI) calc. for $\mathrm{C}_{21} \mathrm{H}_{25} \mathrm{~N}_{4} \mathrm{~S}$ $[\mathrm{M}+\mathrm{H}]^{+}:$365.1, Found: 365.1.

2-Amino-4-(p-tolyl)-6-(p-tolylthio)pyridine-3,5-dicarbonitrile (5f)<smiles>Cc1ccc(Sc2nc(N)c(C#N)c(-c3ccc(C)cc3)c2C)cc1</smiles>

Compound $\mathbf{5 f}$ obtained according to general method with $91 \%$ yield $(324 \mathrm{mg}, 0.91 \mathrm{mmol}$ ) as white crystal, mp 223-224 ${ }^{\circ} \mathrm{C}(\mathrm{EtOH})$ [Lit. mp 222-224 $\left.{ }^{\circ} \mathrm{C}(\mathrm{EtOH})\right]$; ${ }^{11]}{ }^{1} \mathrm{H} \mathrm{NMR}(400 \mathrm{MHz}$, DMSO- $\left._{6}\right) \delta 7.68(\mathrm{~s}, 2 \mathrm{H}), 7.47(\mathrm{dd}, J=14.3,8.4 \mathrm{~Hz}, 4 \mathrm{H}), 7.33-7.24(\mathrm{~m}, 2 \mathrm{H}), 7.10(\mathrm{~d}, J=8.8 \mathrm{~Hz}$, $2 \mathrm{H}), 3.83(\mathrm{~s}, 3 \mathrm{H}), 2.35(\mathrm{~s}, 3 \mathrm{H}) .{ }^{1} \mathrm{H}$ NMR data were in accordance with those reported in the literature. ${ }^{[1]} \mathrm{LRMS} \mathrm{m} / \mathrm{z}$ (ESI) calc. for $\mathrm{C}_{21} \mathrm{H}_{17} \mathrm{~N}_{4} \mathrm{~S}[\mathrm{M}+\mathrm{H}]^{+}$: 357.1, Found: 357.1. 


\section{2-Amino-6-((4-chlorophenyl)thio)-4-phenylpyridine-3,5-dicarbonitrile (5g)}<smiles>Cc1c(Sc2ccc(Cl)cc2)nc(N)c(C#N)c1-c1ccccc1</smiles>

Compound $5 \mathrm{~g}$ obtained according to general method with $89 \%$ yield $(322 \mathrm{mg}, 0.89 \mathrm{mmol}$ ) as white crystal, $\mathrm{mp} 247^{\circ} \mathrm{C}(\mathrm{EtOH})\left[\right.$ Lit. mp $\left.245-247^{\circ} \mathrm{C}\right] ;{ }^{[6]}{ }^{1} \mathrm{H}$ NMR $\left(400 \mathrm{MHz}\right.$, DMSO- $\left.d_{6}\right)$ $\delta 7.82(\mathrm{~s}, 2 \mathrm{H}), 7.70-7.33(\mathrm{~m}, 9 \mathrm{H}) .{ }^{1} \mathrm{H}$ NMR data were in accordance with those reported in the literature. ${ }^{[6]}$ LRMS m/z (ESI) calc. for $\mathrm{C}_{19} \mathrm{H}_{12} \mathrm{ClN}_{4} \mathrm{~S}[\mathrm{M}+\mathrm{H}]^{+}$: 363.0, Found: 363.0.

2-Amino-4-(4-methoxyphenyl)-6-(p-tolylthio)pyridine-3,5-dicarbonitrile (5h)<smiles>COc1ccc(-c2c(C)c(Sc3ccc(C)cc3)nc(N)c2C#N)cc1</smiles>

Compound $5 \mathrm{~h}$ obtained according to general method with $82 \%$ yield $(305 \mathrm{mg}, 0.82 \mathrm{mmol}$ ) as white crystal, mp $230-231{ }^{\circ} \mathrm{C}(\mathrm{EtOH})$ [Lit. mp $229-231{ }^{\circ} \mathrm{C}$ ]; ${ }^{[4]}{ }^{1} \mathrm{H}$ NMR $(400 \mathrm{MHz}$, $\left.\mathrm{CDCl}_{3}\right) \delta 7.50(\mathrm{~d}, J=8.8 \mathrm{~Hz}, 2 \mathrm{H}), 7.42(\mathrm{~d}, J=8.1 \mathrm{~Hz}, 2 \mathrm{H}), 7.25(\mathrm{~d}, J=8.1 \mathrm{~Hz}, 2 \mathrm{H}), 7.04(\mathrm{~d}$, $J=8.8 \mathrm{~Hz}, 2 \mathrm{H}), 5.46(\mathrm{~s}, 2 \mathrm{H}), 3.87(\mathrm{~s}, 3 \mathrm{H}), 2.41(\mathrm{~s}, 3 \mathrm{H}) .{ }^{1} \mathrm{H}$ NMR data were in accordance with those reported in the literature. ${ }^{[4]} \mathrm{LRMS} \mathrm{m} / \mathrm{z}$ (ESI) calc. for $\mathrm{C}_{21} \mathrm{H}_{17} \mathrm{~N}_{4} \mathrm{OS}[\mathrm{M}+\mathrm{H}]^{+}$: 373.1, Found: 373.1.

2-Amino-4-(4-nitrophenyl)-6-(p-tolylthio)pyridine-3,5-dicarbonitrile (5i)<smiles>Cc1ccc(Sc2nc(N)c(C#N)c(-c3ccc([N+](=O)[O-])cc3)c2C)cc1</smiles>

Compound $5 \mathrm{i}$ obtained according to general method with $88 \%$ yield $(341 \mathrm{mg}, 0.88 \mathrm{mmol})$ as white crystal, $\mathrm{mp} 298^{\circ} \mathrm{C}(\mathrm{EtOH})\left[\mathrm{Lit} . \mathrm{mp} 300-302{ }^{\circ} \mathrm{C}\right.$ ]; ${ }^{[7]} 1 \mathrm{H}$ NMR $\left(400 \mathrm{MHz}\right.$, DMSO- $\left.d_{6}\right)$ $\delta 8.25(\mathrm{~d}, J=8.7 \mathrm{~Hz}, 2 \mathrm{H}), 7.70(\mathrm{~d}, J=8.4 \mathrm{~Hz}, 2 \mathrm{H}), 7.28(\mathrm{~d}, J=8.4 \mathrm{~Hz}, 2 \mathrm{H}), 7.15(\mathrm{~d}, J=7.7 \mathrm{~Hz}$, $2 \mathrm{H}), 2.25(\mathrm{~s}, 3 \mathrm{H}) .{ }^{1} \mathrm{H}$ NMR data were in accordance with those reported in the literature. ${ }^{[7]}$ LRMS m/z (ESI) calc. for $\mathrm{C}_{20} \mathrm{H}_{14} \mathrm{~N}_{5} \mathrm{O}_{2} \mathrm{~S}[\mathrm{M}+\mathrm{H}]^{+}: 388.1$, Found: 388.1 .

2-Amino-6-((4-bromophenyl)thio)-4-phenylpyridine-3,5-dicarbonitrile (5j)<smiles>Cc1c(Sc2ccc(Br)cc2)nc(N)c(C#N)c1-c1ccccc1</smiles>

Compound $5 \mathbf{j}$ obtained according to general method with $74 \%$ yield ( $301 \mathrm{mg}, 0.74 \mathrm{mmol}$ ) as white crystal, mp $255-257^{\circ} \mathrm{C}(\mathrm{EtOH})$ [Lit. mp 256-258 ${ }^{\circ} \mathrm{C}$; ${ }^{[3]}{ }^{1} \mathrm{H}$ NMR $(400 \mathrm{MHz}$, DMSO- $\left.d_{6}\right) \delta 7.83(\mathrm{~s}, 2 \mathrm{H}), 7.67(\mathrm{~d}, J=8.1 \mathrm{~Hz}, 2 \mathrm{H}), 7.55(\mathrm{dd}, J=11.3,5.6 \mathrm{~Hz}, 7 \mathrm{H}) .{ }^{1} \mathrm{H}$ NMR data were in accordance with those reported in the literature. ${ }^{[3]}$ LRMS $\mathrm{m} / \mathrm{z}$ (ESI) calc. for $\mathrm{C}_{19} \mathrm{H}_{12} \mathrm{BrN}_{4} \mathrm{~S}[\mathrm{M}+\mathrm{H}]^{+}$: 406.9, Found: 406.9. 
2,4-Diamino-5-[(4-methylphenyl)thio]-5H-[1]benzopyrano[2,3-b]pyridine-3carbonitrile (5k)<smiles>Cc1ccc(SC2c3ccccc3Oc3nc(N)c(C#N)c(N)c32)cc1</smiles>

Compound 5k obtained according to general method with $79 \%$ yield $(285 \mathrm{mg}, 0.79 \mathrm{mmol})$ as white crystal, $\mathrm{mp} 224{ }^{\circ} \mathrm{C}(\mathrm{EtOH})$ [Lit. mp $\left.223-225^{\circ} \mathrm{C}\right] ;{ }^{[8]}{ }^{1} \mathrm{H}$ NMR $\left(400 \mathrm{MHz}\right.$, DMSO- $\left.d_{6}\right)$ $\delta 7.17(\mathrm{~d}, J=7.4 \mathrm{~Hz}, 2 \mathrm{H}), 7.07(\mathrm{td}, J=7.2,6.6,1.2 \mathrm{~Hz}, 1 \mathrm{H}), 6.96-6.84(\mathrm{~m}, 4 \mathrm{H}), 6.80(\mathrm{~d}$, $J=1.0 \mathrm{~Hz}, 1 \mathrm{H}), 6.63(\mathrm{~d}, J=8.1 \mathrm{~Hz}, 2 \mathrm{H}), 6.43(\mathrm{~s}, 2 \mathrm{H}), 5.67(\mathrm{~s}, 1 \mathrm{H}), 2.20(\mathrm{~s}, 3 \mathrm{H}) .{ }^{1} \mathrm{H}$ NMR data were in accordance with those reported in the literature. ${ }^{[8]}$ LRMS $\mathrm{m} / \mathrm{z}$ (ESI) calc. for $\mathrm{C}_{20} \mathrm{H}_{17} \mathrm{~N}_{4} \mathrm{OS}[\mathrm{M}+\mathrm{H}]^{+}$: 361.1, Found: 361.1 .

\subsection{Microorganisms and Media}

All bacterial strains were received and statistically analysed, as described in [5-55].

Table 2. The MCR toward 5a, catalyzed by different enzymes ${ }^{[a]}$.

\begin{tabular}{ccccc}
\hline Entry & Catalyst & T $\left({ }^{\circ} \mathbf{C}\right)$ & Solvent & Yield [\%] \\
\hline 1 & None & 40 & cyclohexane & 4 \\
2 & Porcine pancreas lipase (PPL) & 40 & cyclohexane & 31 \\
3 & Porcine pancreas lipase (PPL) & 40 & $\mathrm{H}_{2} \mathrm{O}$ & 49 \\
4 & Porcine pancreas lipase (PPL) & 40 & EtOH & 83 \\
5 & Porcine pancreas lipase (PPL) & 40 & MeCN & 52 \\
6 & Porcine pancreas lipase (PPL) & 40 & DMF & 24 \\
7 & Porcine pancreas lipase (PPL) & 40 & DMSO & 33 \\
8 & Porcine pancreas lipase (PPL) & 50 & EtOH & 75 \\
9 & Porcine pancreas lipase (PPL) ${ }^{\text {b }}$ & 40 & EtOH & 80 \\
10 & Pseudomonas fluorescens lipase (PFL) & 40 & cyclohexane & 11 \\
11 & Candida rugosa lipase (CRL) & 40 & cyclohexane & 16 \\
12 & Candida cylindracea lipase (CCL) & 40 & cyclohexane & 18 \\
13 & Novozym 435 & 40 & cyclohexane & 4 \\
14 & Bovine serum albumin (BSA) & 40 & cyclohexane & 8 \\
15 & Pig liver acetone powder (PLAP) ${ }^{\mathrm{c}}$ & 40 & cyclohexane & 14 \\
16 & Denatured PPL d & 40 & cyclohexane & 6 \\
\hline a & deaction &
\end{tabular}

a Reaction conditions: 4-cyanobenzaldehyde (1 mmol), malononitrile (2 mmol) and 4-methylthiophenol, and enzyme $(100 \mathrm{mg})$ in solvent $(2 \mathrm{~mL})$ for $18 \mathrm{~h}, 200 \mathrm{rpm} .{ }^{\mathrm{b}}$ PPL $(120 \mathrm{mg}),{ }^{\mathrm{c}}$ Domestically prepared. ${ }^{\mathrm{d}}$ Thermally deactivated. ${ }^{e}$ Yield of the isolated product $5 a,[29,36]$.

\section{Results}

\subsection{Chemistry}

Heterocyclic compounds are the largest class of organic compounds. Many natural products and most drugs have heterocyclic rings. Antibiotics, dyes of flowers and other plants, compounds that transport oxygen to various organs of our body, and DNA components are heterocyclic compounds. They can be of different sizes, have multiple bonds, and can be linked by chains or rings. Among the heterocyclic compounds, heterocyclic nitrogen and oxygen compounds deserve special attention. The synthesis of pyridine derivatives, aiming to develop new drugs, is an active research area. The general method for the preparation of 2-amino-4-aryl-3,5-dicarbonitrile-6-sulfanylpyridines is based on a multicomponent condensation reaction (MCR) between aldehydes, malononitrile (two equiv.), and thiols in the presence of a catalyst $[17,18]$. Various catalysts have been reported to effect MCR, including nano-crystalline magnesium oxide, [19] silica nanoparticles [20], $\mathrm{ZnCl}_{2}$ [21], piperidine/microwave [22] and Cd(II) metal-organic frameworks [23], refluxed in basic alumina [24]. Although the reported methods are efficient to provide the desired 
2-amino-4-aryl-3,5-dicarbonitrile-6-sulfanylpyridines, there are still some drawbacks regarding these protocols, such as their longer reaction time, limited substrate scope, and complicated work-up processes, as well as the application of expensive, highly toxic and carcinogenic transition metal catalysts. Therefore, the development of a catalyst system that does not contain harmful components such as transition metals, strong acids or bases seems desirable.

As a part of our ongoing research into environmentally sustainable protocols [25-28], we devoted our attention to the development of a protocol for the desired 2-amino-4-aryl3,5-dicarbonitrile-6-sulfanylpyridines, which combines both economic and green chemistry aspects. Although several methods have recently been reported regarding the synthesis of 2-amino-4-aryl-3,5-dicarbonitrile-6-sulfanylpyridines [37-44], the biocatalytic approach to target compounds is strictly limited to the application of a whole cell of Baker yeast [29]. As a result of our intensive work on the development of an effective method for the synthesis of pharmaceutically relevant compounds [30,31], we wish to report hydrolases as a sustainable catalyst for MCR, leading to the target pyridines 5 [32-35].

Based on our previous studies on promiscuous enzyme activity [34] the model MCR of 4-cyanobenzaldehyde (1 mmol), malononitrile $(2 \mathrm{mmol})$ and 4-methylthiophenol was used in cyclohexane at $40 \circ \mathrm{C}$ (Figure 2), (Table 2, entry 1).

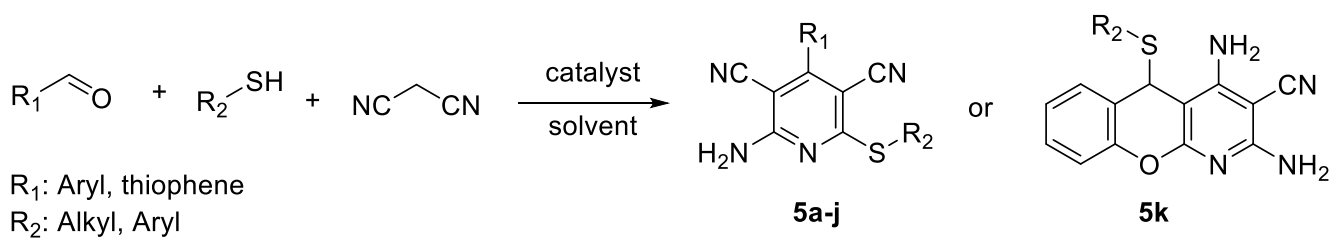

Figure 2. Enzyme-catalyzed synthesis of pyridines $\mathbf{5 a - k}$.

To screen the suitable medium, we performed the model reaction in different solvents: water, ethanol, acetonitrile, $\mathrm{N}, \mathrm{N}$-dimethyl formamide (DMF) and dimethyl sulfoxide (DMSO). The obtained results are summarized in Table 2. Protic solvents such as $\mathrm{H}_{2} \mathrm{O}$ and $\mathrm{EtOH}$ were found to enhance the reaction yield of the product 5a. The obtained results remained in agreement with the literature data [29]. To evaluate the effect of temperature, the model reaction was carried out at a temperature that was increased to $50^{\circ} \mathrm{C}$; however the yield was reduced above $40{ }^{\circ} \mathrm{C}$, providing product $5 \mathbf{a}$ with $75 \%$, which may be explained by the changes in the tertiary structure of the used enzyme (Table 2, entry 2, 8,9).

We applied the developed reaction conditions using various aldehydes and thiophenols, which resulted in substituted pyridines $\mathbf{5 b} \mathbf{b}-\mathbf{k}$ with high yields (Table 1 ). The structures of the obtained products 5 were verified by a comparison of spectral data (NMR and mass) and melting point temperatures with the literature data for title compounds. The characterization data of the synthetized compounds $5 \mathbf{a}-\mathbf{k}$ are presented in the experimental part.

\subsection{Toxicity of Piryidine Derivatives}

In our current studies into the toxicity of pyridine derivatives on model E. coli bacterial cells, we used MIC and MBC tests, similar to our earlier experiments [45-50]. They consisted of examining the rate of migration of the analyzed compounds through the bacterial membranes that may be damaged by them, which, in turn, may lead to apoptosis of the bacterial cell. This is especially visible when the color of the analyzed sample changes after the addition of a special resazurin dye, which changes its color from dark blue to pink, orange or yellow [45-52]. As a result of irreversible damage to the bacterial membrane by a given compound, the dye penetrates with varying intensity, but only reaches dead cells (Figures S1-S3 in Supplementary Materials).

The experiments were carried out using new methods of synthesizing 11 new compounds-pyridine derivatives 5 (Figures 1 and 2, Tables 1 and 2), containing basic three, four or more fused aromatic rings in their basic structure, connected by various functional groups, such as sulfur $(\mathrm{S})$, nitrogen $(\mathrm{N})$, amino $\left(\mathrm{NH}_{2}\right)$, cyanide $(\mathrm{CN})$, chlorine $(\mathrm{Cl})$, bromine 
(Br), methyl (OMe) and nitrogen $\left(\mathrm{NO}_{2}\right)$, at the $\mathrm{R}_{1}$ or $\mathrm{R}_{2}$ position. The research investigated the influence of these groups, which are attached to the rings of pyridine derivatives (compounds 5a, 5b, 5c, 5d, 5e, 5f, 5g, 5h, 5i, 5j, 5k).

The toxic effect on bacterial cells after the analysis of the MIC and MBC test for all 11 analyzed compounds was obtained for the compounds marked in our study, with symbols as in $\mathbf{5 a}$ and $\mathbf{5 g} \mathbf{- 5 k}$, for which the MIC values were observed in the range of $0.2-1.3 \mu \mathrm{g} / \mathrm{mL}$, and $10-42 \mu \mathrm{g} / \mathrm{mL}$ for MBC values in the analyzed model strains $\mathrm{K} 12$, R2, $\mathrm{R} 3$ and R4) (Figures 3 and 4), which had specific functional groups in the structure of the $R_{1}$ and $R_{2}$ substituent. The antimicrobial activity of the selected pyridine derivatives was determined on the basis of the MBC values for the analyzed compounds, which ranged from 30 to $45 \mu \mathrm{g} / \mathrm{mL}$ (Figure 5). The indicator showed an increase in the value from about 160 to $250 \mu \mathrm{g} / \mathrm{mL}$ in E. coli R2-R4 strains compared to the K12 strain, where, in all the analyzed MIC and MBC tests, due to the lack of LPS in its structure (Figures 3-5), values remained at the very low level of slightly above zero $(0.12-0.21 \mu \mathrm{g} / \mathrm{mL}$ for MIC and $1-4 \mu \mathrm{g} / \mathrm{mL}$ for MBC), (Figures 3 and 4 ) and (0-25 $\mu \mathrm{g} / \mathrm{mL}$ for MBC/MIC) (Figure 5).

In the analyzed MIC plates, after using all the analyzed compounds (Figure S1 in Supplementary Materials), for the reference E. coli strain K12, a color change was observed at a dilution of 10-6, which corresponds to an MIC value of $0.003225 \mu \mathrm{g} / \mathrm{mL}^{-1}$ in all analyzed reactions. On panel B, a dilution in an R2 strain was on the level of 10-3, especially for compounds marked as 1,3,7,8,9,10,11 (corresponding to $\mathbf{5 a}, \mathbf{5 c}, \mathbf{5} \mathbf{g}-\mathbf{5 k}$ ), containing substituents such as CN, S and Br. The MIC values for these compounds were $0.027 \mu \mathrm{g} / \mathrm{mL}^{-1}$. For the remaining analyzed compounds in the $\mathrm{R}_{2}$ substituent, the color change was visible at a dilution of 10-5, which corresponds to an MIC value of $0.00525 \mu \mathrm{g} / \mathrm{mL}^{-1}$. The observed color change was more intense than in the other analyzed compounds. This proves the permanent and irreversible destruction of the bacterial membrane, and the LPS of a certain length contained in it, by the analyzed compounds in the R2 skeleton. This was observed in the R3 and R4 strains. The relationships between the analyzed strains and compounds are shown in Figures 3-5 and in Figure S1 in the Supplementary Materials and in Table 3.

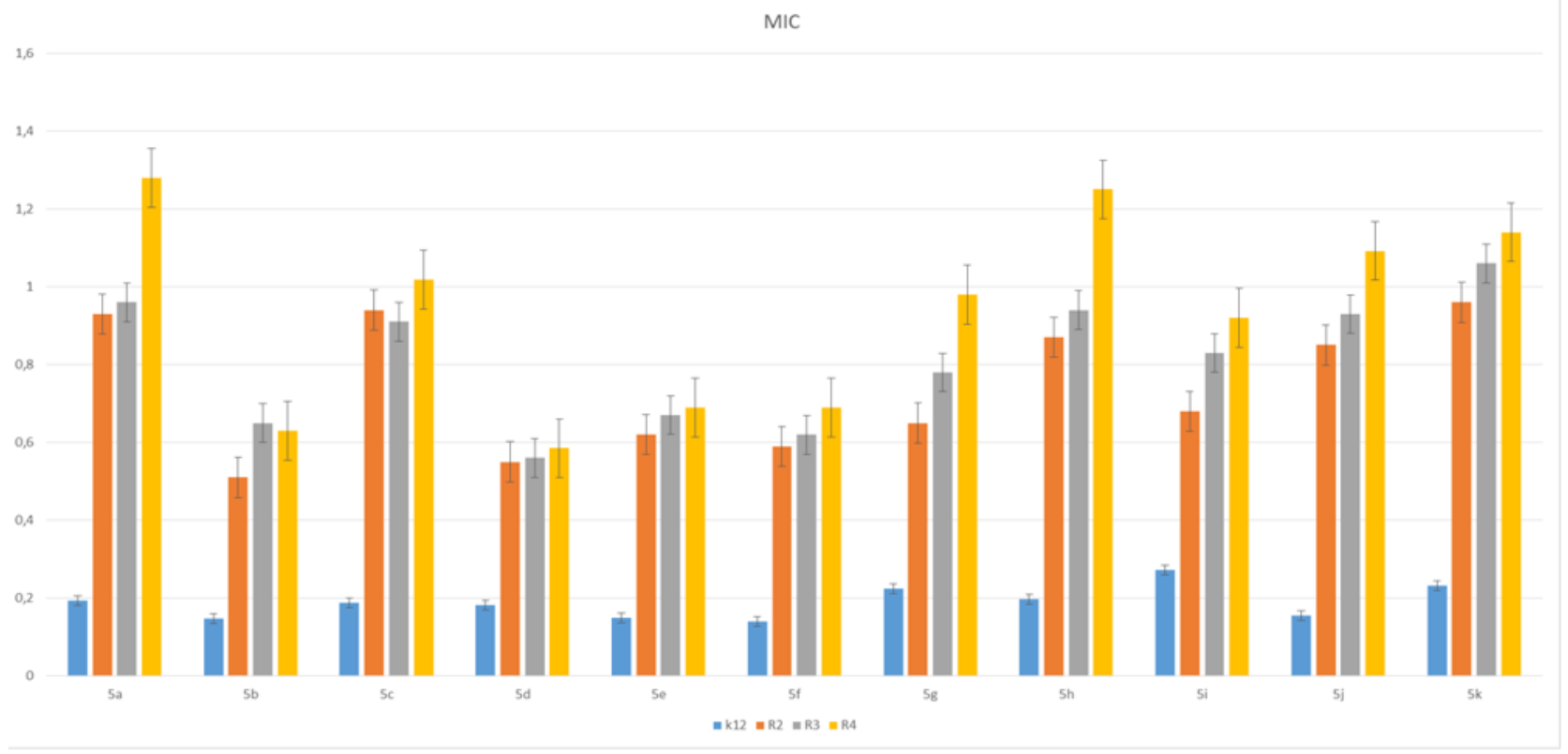

Figure 3. Minimum inhibitory concentration (MIC) of the pyridine derivatives in model bacterial strains. The $x$-axis 11 compounds were used sequentially. The $y$-axis shows the MIC value in $\mu \mathrm{g} / \mathrm{mL}^{-1}$. 
$\mathrm{MBC}$

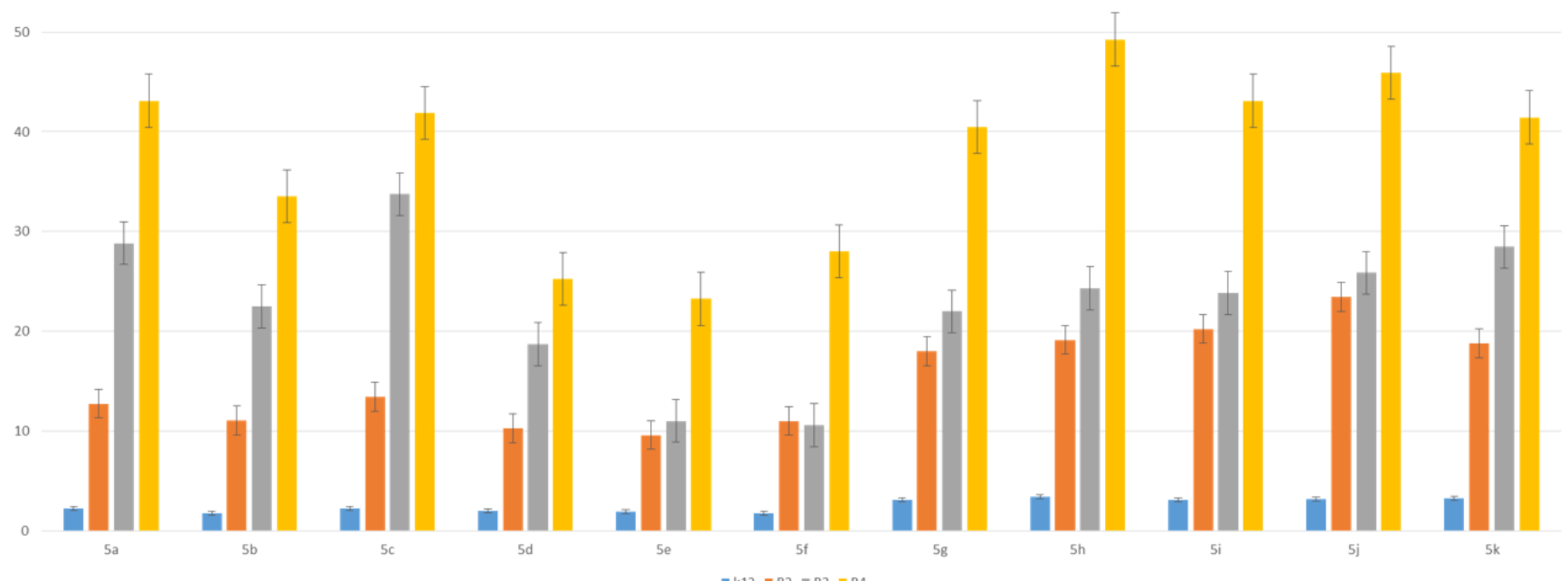

Figure 4. MBC of the pyridine derivatives in model bacterial strains. The $x$-axis 11-compounds were used sequentially. The $y$-axis shows the $\mathrm{MBC}$ value in $\mu \mathrm{g} / \mathrm{mL}^{-1}$.

$\mathrm{MBC} / \mathrm{MIC}$

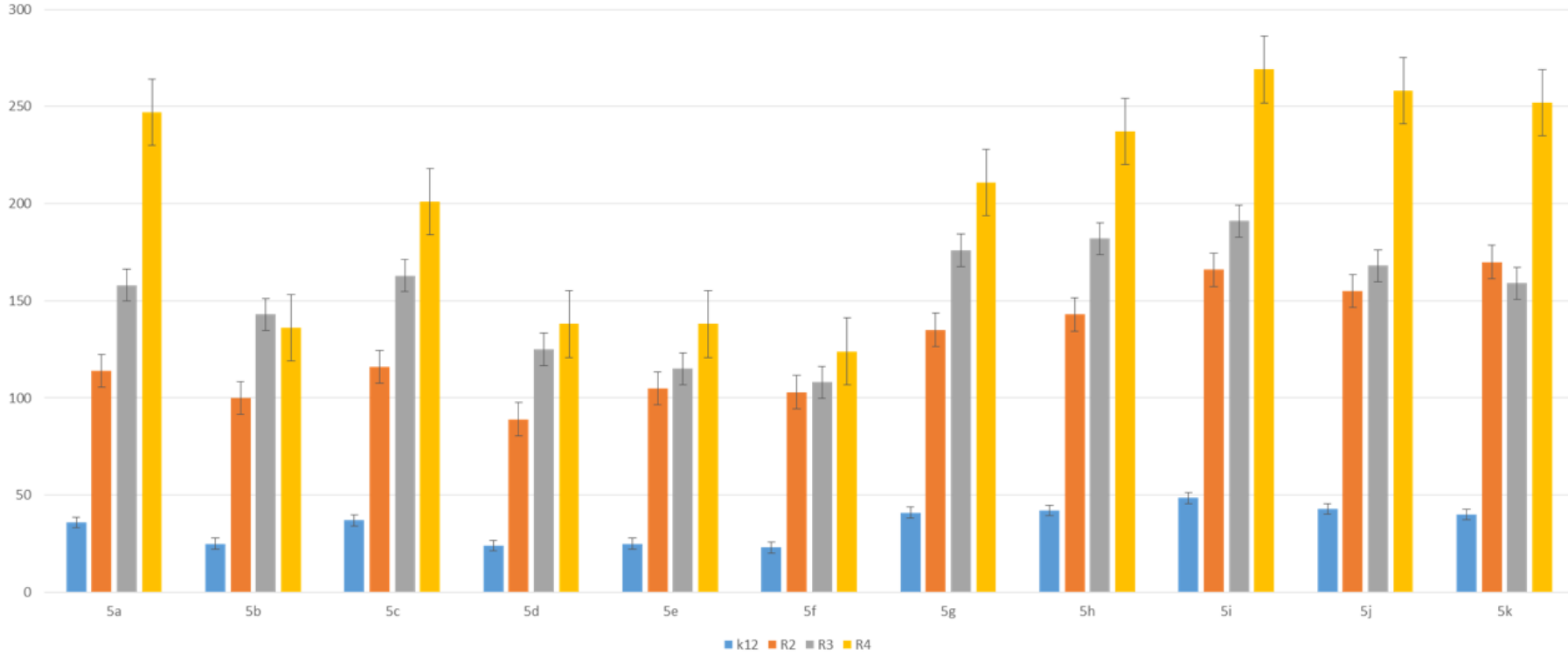

Figure 5. $\mathrm{MBC} / \mathrm{MIC}$ of the pyridine derivatives in model bacterial strains. The $x$-axis compounds 1-11 were used sequentially. The $y$-axis shows the $\mathrm{MBC} / \mathrm{MIC}$ value in $\mu \mathrm{g} / \mathrm{mL}^{-1}$. 
Table 3. Statistical analysis of all 11 analyzed compounds at $p<0.05^{*},<0.01^{* *},<0.001^{* * *}$ in MIC, MBC and MBC/MIC tests. Pyridine derivatives 1-11 were used sequentially.

\begin{tabular}{ccccccccccccc}
\hline No of Samples & $\mathbf{1}$ & $\mathbf{2}$ & $\mathbf{3}$ & $\mathbf{4}$ & $\mathbf{5}$ & $\mathbf{6}$ & $\mathbf{7}$ & $\mathbf{8}$ & $\mathbf{9}$ & $\mathbf{1 0}$ & $\mathbf{1 1}$ & Type of Test \\
\hline K12 & $* * *$ & $*$ & $* *$ & $*$ & $*$ & $*$ & $* *$ & $* * *$ & $*$ & $* *$ & $* *$ & \\
R2 & $* * *$ & $*$ & $* *$ & $*$ & $*$ & $*$ & $* *$ & $* * *$ & $*$ & $* * *$ & $* *$ & MIC \\
R3 & $* * *$ & $*$ & $* *$ & $*$ & $*$ & $*$ & $* *$ & $* * *$ & $*$ & $* *$ & $* *$ & MIC \\
R4 & $* * *$ & $*$ & $* *$ & $*$ & $*$ & $*$ & $* *$ & $* *$ & $*$ & $* *$ & $* *$ & MIC \\
K12 & $* * *$ & $*$ & $* *$ & $*$ & $*$ & $*$ & $* *$ & $* *$ & $*$ & $* *$ & $* *$ & MIC \\
R2 & $* *$ & $*$ & $* *$ & $*$ & $*$ & $*$ & $* *$ & $* *$ & $*$ & $* *$ & $* * *$ & MBC \\
R3 & $* *$ & $*$ & $* *$ & $*$ & $*$ & $*$ & $* *$ & $* *$ & $*$ & $* *$ & $* *$ & MBC \\
R4 & $* *$ & $*$ & $* *$ & $*$ & $*$ & $*$ & $* *$ & $* *$ & $*$ & $* *$ & $* *$ & MBC \\
K12 & $*$ & $*$ & $* *$ & $*$ & $*$ & $*$ & $*$ & $*$ & $*$ & $* *$ & $*$ & MBC/MIC \\
R2 & $*$ & $*$ & $*$ & $*$ & $*$ & $*$ & $*$ & $*$ & $*$ & $* *$ & $*$ & MBC/MIC \\
R3 & $*$ & $*$ & $*$ & $*$ & $*$ & $*$ & $*$ & $*$ & $*$ & $* *$ & $*$ & MBC/MIC \\
R4 & $*$ & $*$ & $*$ & $*$ & $*$ & $*$ & $*$ & $*$ & $*$ & $* *$ & $*$ & MBC/MIC \\
\hline
\end{tabular}

3.3. Modification of Plasmid DNA Isolated from E. coli R2-R4 Strains with Tested Pirydine Derivatives

Based on the results of MIC and MBC toxicity tests in the analyzed model of bacterial (Figure S1 in the Supplementary Materials), it was decided to modify the bacterial DNA with the analyzed pyridine compounds. On the basis of the obtained results for the modification of bacterial DNA, we observed that, in the R4 strain, there was a very distinct change in the structure caused by changing the ratio of the topological forms of the ccc, linear and oc plasmid DNA to each other, and the formation of densely looped structures forming the so-called concatamers, the formation of which may be caused by bacterial DNA topoisomerases (Figure S2 in the Supplementary Materials). No such visible and significant changes in the structure were observed in the bacterial DNA obtained and modified from other strains, K12, R2 and R3. For further analysis with the Fpg protein (which is a bifunctional glycosylase and recognizes oxidized DNA bases such as 8oxoG, FapyA and FapyG) [45-50], we used plasmid DNA. Since we observed the greatest number of modifications after treatment with the Fpg protein in the R4 strain, we present its values as an exemplary model (Figure S2 in the Supplementary Materials). As the greatest damage, after modification with pyridine derivatives and antibiotics after digestion with Fpg protein, was visible in the R4 strain, we present it as an example in the Supplementary Materials.

After treatment with Fpg glycosase in strain R4, we observed clearly visible damage in the topological changes in plasmid DNA forms; "ccc", linear form and "oc", which have been completely damaged and are only visible as stray bands (see Figure 6, Figures S2 and S3 in the Supplementary Materials) according to the earlier literature (data [45-50]). 


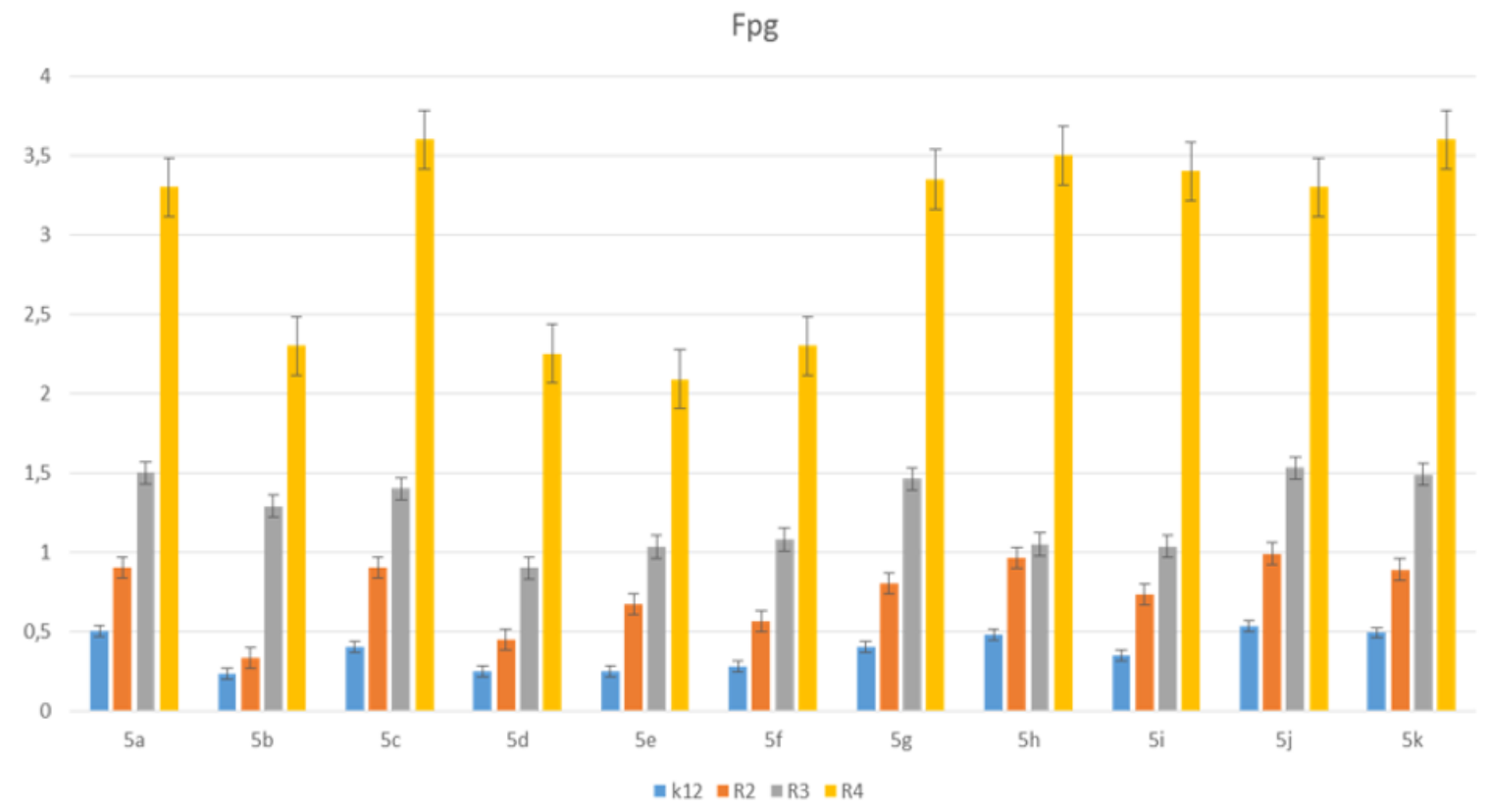

Figure 6. Percent of digested DNA damages recognised by Fpg enzyme- ( $y$-axis) with control K12 and R2-R4 strains ( $x$-axis); The selected compounds $\mathbf{1 - 1 7}$ were statistically significant at $p<0.05$ *

The next step in our research was to use pyridine derivatives as a function of the commonly used beta-lactam antibiotics in the treatment of specific bacterial infections, which include kanamycin, streptomycin, ciprofloxacin, bleomycin and cloxacillin, a component of the drug syntarpen. They are mainly used in skin and soft tissue infections, lower respiratory tract infections and osteomyelitis. As in our previous experiments [45-48], we also used three antibiotics as a reference compounds in the present study to test their effect on the analysed pyridine derivatives (Figure 7). The experimental system used was identical to the analyzed compounds [45-48] with the use of MIC and MBC tests in terms of quantity and concentration (Figure S1 in the Supplementary Materials) and for bacterial DNA isolated from the bacteria modified by these antibiotics and digested with protein Fpg. We observed that, in all analyzed R-type strains, based on the MIC and MBC tests, there was a visible color change in the analyzed antibiotics used at a dilution of 10-3 (Figure S1 in the Supplementary Materials), which corresponds to the values of $0.027 \mu \mathrm{g} / \mathrm{mL}^{-1}$ in the analyzed MIC (Figure S1 Supplementary Materials). It was also shown that the R4 strain, having the longest LPS, interacts with all active groups included in the analyzed antibiotics. The obtained results were also statistically significant at the level of $p<0.05$. In the analyzed pyridine derivatives, especially in compounds 1,3,7-10 (which corresponds to the determinations in graphs $\mathbf{5 a}, \mathbf{5} \mathbf{c}, \mathbf{5} \mathbf{g}-\mathbf{5 k}$ ), the MIC values were similar to the values in the model strain R4, which proves that these compounds can also potentially be used as "alternatives" to commonly used antibiotics. 


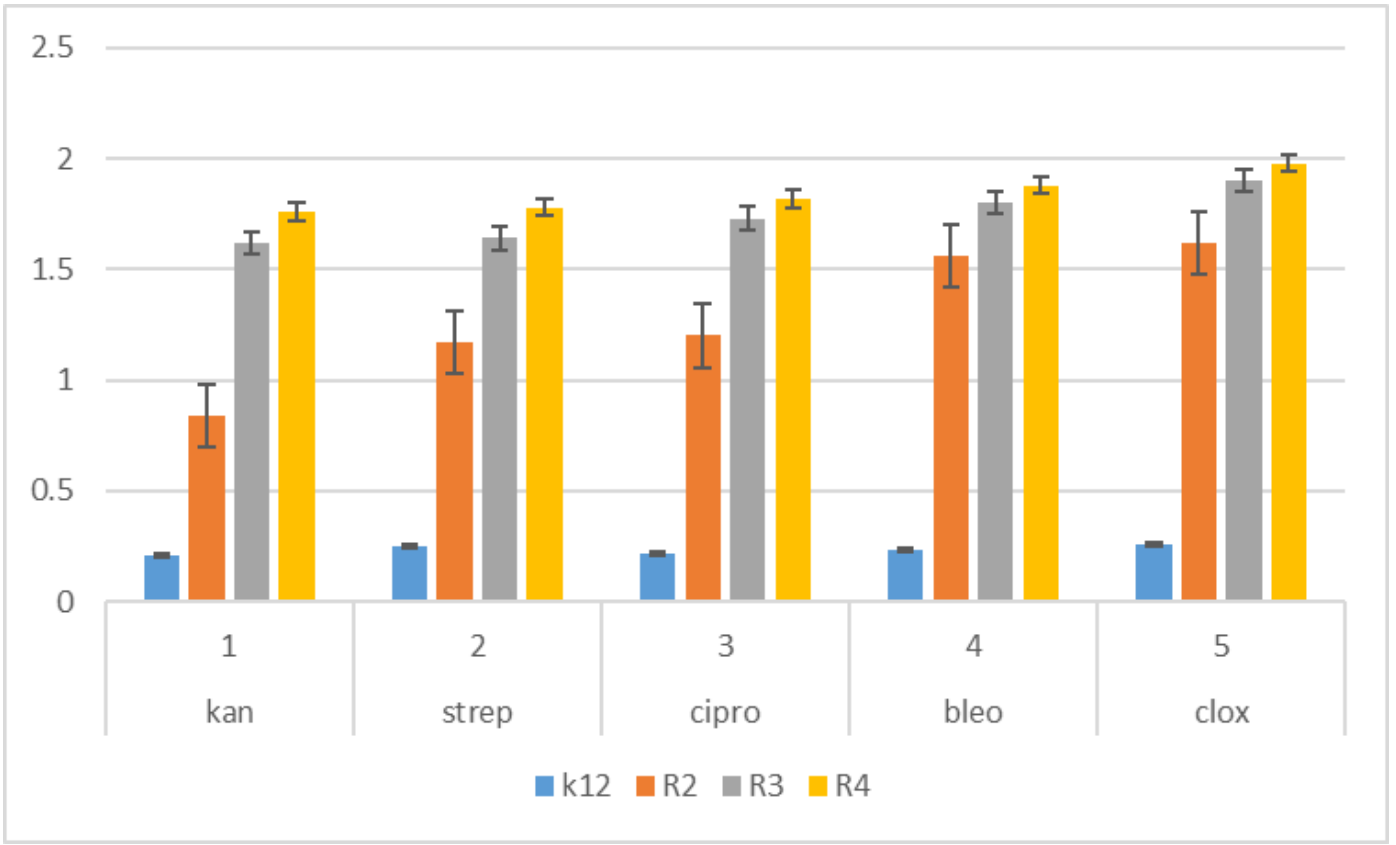

Figure 7. Examples of MIC with model bacterial strains K12, R2, R3, and R4 of the studied antibiotics with kanamycin, streptomycin, ciprofloxacin, bleomycin and cloxacillin. The $x$-axis features antibiotics that were used sequentially. The $y$-axis features the MIC value in $\mu \mathrm{g} / \mathrm{mL}^{-1}$.

In all analyzed nucleic acids after modification with antibiotics and digestion with Fpg protein, changes in all topological forms were observed in various proportions (Figure S3 Supplementary Materials). These lesions were similar to those observed after modification with selected pyridine derivatives and digestion with Fpg protein, but significantly weaker (Figure 8). This may indicate that the modification with an appropriate antibiotic in bacterial DNA constituted additional new substrates recognized by the Fpg protein, whose structure was similar to that of the pyridine derivatives also recognized by this protein.

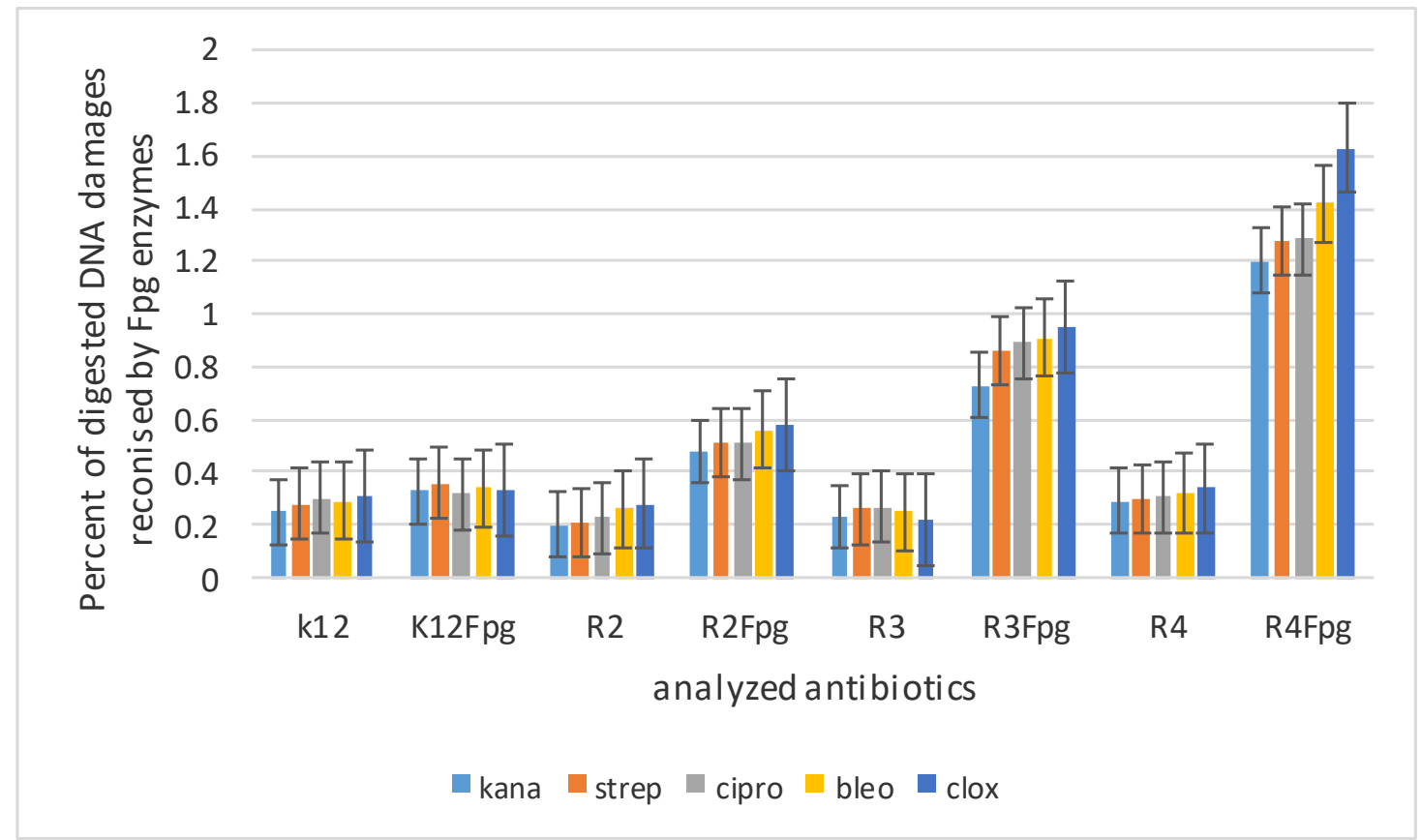

Figure 8. Percentage of bacterial DNA recognized by Fpg enzyme in model bacterial strains after kanamycine, sterpromycine, ciprofloxacin, bleomycine and cloxsacilline treatment. The compounds were statistically significant at $p<0.05$. 
In the nucleic acids isolated from the R4 strain after modification with cloxacillin and digestion with the Fpg protein, two additional forms appeared over the traditional topological plasmids ccc and oc, which indicates the formation of additional looped structures in the bacterial genetic material. This effect was especially visible after modification with 1,3,7-10 compounds containing $\mathrm{C}, \mathrm{S}, \mathrm{CN}, \mathrm{Br}$ as a substituent function. In the remaining analyzed samples, digested with the same antibiotic and not digested with the Fpg protein, the occurrence of all topological forms of the plasmid was unchanged. After digestion of these samples, trailing bands of topological plasmid forms appeared, which were rearranged as a result of digestion with the Fpg protein, showing oxidative base modifications in bacterial DNA as "smear". Their intensity varied depending on the pyridine derivative used (Figures S4 and S5 in Additional Materials).

The highest values (ranged from 2.7 to $3.3 \%$ ) of the observed damage in plasmid DNA were observed for the pyridine derivatives numbered 1,3,7-10, and similarly for the samples modified with cloxacillin, in which the R4 strain was the highest (R4 > R2 > R3 > K12), as in our earlier studies [45-48].

This proves that they damage the DNA of the bacterial cell more than the analyzed antibiotics by interfering with its structure (disturbed structural topological forms of bacterial DNA). This indicates a very high toxicity of the analyzed pyridine derivatives towards bacterial DNA, caused by the significant modification of the components of the bacterial membrane and the LPS contained in it, which may activate bacterial topoisomerases, allowing for the relaxation of the structure and access to the modified, exposed DNA bases.

Presumably, stabilization of the topoisomerase-controlling complex is necessary for the cell to survive. Blocking these enzymes blocks replication and transcription, which can affect the total amount of super-replicated DNA.

\section{Discussion}

The toxicity of selected pyridine derivatives on model strains of E. coli containing LPS -R2-R4 in their structure (or a lack of K12 strain) determines them as potentially new drug precursors to commonly and traditionally used antibiotics [37-44].

The use of model strains of E. coli makes it possible to understand the exact mechanism of the destruction of the bacterial cell membrane and the changes in the redox potential of its individual components.

All 11 compounds used on model bacterial cells were highly toxic, especially the seven containing $C N, N_{2}$ groups and $S, N, B r$ atoms in certain positions in the $R_{1}$ and $R_{2}$ substituents. These showed the highest antibacterial effectiveness. The highest values in both types of MIC and MBC assay, and the highest percentage of modifications identified after digestion with Fpg protein, were observed for compounds marked as 1, 3, 7-11 (corresponding to the determinations in compounds $\mathbf{5 a}, \mathbf{5 c}, \mathbf{5} \mathbf{g}-\mathbf{5 k}$, respectively). This indicates that the type of the substituent and specific number of aromatic rings determine its toxic effect on model E. coli bacterial cells that differ in LPS length in ascending order $\mathrm{R} 2<\mathrm{R} 3<\mathrm{R} 4$. The analysis of the literature data shows that the analyzed strains can cause civilization diseases related to the dysfunction of various organs and tissues in the human body [45-52].

The effect of the analysed compounds on the bacterial membrane was very similar to the interaction of ionic liquids containing quaternary ammonium surfactants and other analyzed compounds, such as coumarin derivatives, 1,2-diaaryl alcohols and lactones [45-52].

Changes in the activity of bacterial cells under the influence of pyridine derivatives probably result from the strong activation of oxidative stress in the bacterial cell at its cell membrane, which, at a later stage, leads to apoptosis as a result of further penetration into the genetic material. This leads to its destruction through the modification and inhibition of the replication apparatus leading to apoptosis [50-55].

The obtained results constitute the basis for the continuation of research into other bacterial strains associated with human civilization diseases and identification of hospital infections. In addition to the MIC and MBC tests, the analyzed pyridine derivatives were 
analyzed for the digestion of modified plasmids isolated from strains K12 and R2, R3 and R4 by the Fpg protein with N-glycosylase/AP lyase activity [50-55].

The number of damaged plasmids which were modified by pyridine derivatives was determined on the basis of the rearrangement of topological changes in bacterial DNA forms additionally digested with Fpg glycosylase. On the basis of numerous literature reports, it was found that the Fpg protein has a very wide-ranging removal of modified bases as a result of oxidation and alkylation processes, with the active participation of free oxygen radicals induced by ROS or RNS. At present, it is believed in many domestic and foreign laboratories that this protein is an extremely precise and very sensitive marker of DNA oxidative damage formed in the bacterial cell in the process of oxidative stress induced by factors of internal origin, e.g., lipid peroxidation, alkylation, methylation of DNA bases, etc., as well as external origin such as ionizing radiation. It is estimated that the amount of oxidation in bacterial DNA at the level of $3-4 \%$, caused by the aforementioned factors and recognized by the Fpg enzyme, is an important indicator of the modification of individual DNA bases, including guanine, leading to the formation of 8oxoguanine (8oxoG), FapyGua (FapyG) or modification of adenine to form Fapy Ade (FapyA) in a particular matrix [45-55].

In studies with pyridine derivatives, changes in the topological forms of bacterial DNA were observed for seven of the 11 analyzed compounds after digestion with Fpg protein. These changes consisted of mixing all forms in the form of "smearing" bands after digestion with Fpg protein, and modified bacterial plasmids. This suggests that these are new potential substrates for this protein [45-55].

The obtained results show that the analyzed pyridine derivatives significantly modify the bacterial DNA isolated from the model strains of E. coli, K12 and R. These modifications are recognized by the Fpg protein (Figures S2 and S3 in Supporting Material). The most effective pyridine derivatives were compounds $\mathbf{5 a}, \mathbf{5 c}, \mathbf{5 g}-\mathbf{5 k}$. This means that, in the future, some of these analyzed compounds could be modified to be innovative, less toxic to the human body and more toxic to bacterial cells. They could be considered as potential drugs, and used as substitutes for antibiotics with a similar chemical structure. It is now known that the constant and frequent use of antibiotics results in the acquisition of immunity for many bacteria, including pathogenic ones [53]. Therefore, in our experiments we tested five commonly used antibiotics-kanamycin, streptomycin, cloxacycline, blemycin and ciprofloxacin - which are used in patients with cardiovascular and digestive system infections caused by staphylococci of the genus Stahylococcus areus [45-50]. These antibiotics have a very broad spectrum of activity against Gram-negative bacteria, including E. coli [45-50], as demonstrated on the respective MIC and MBC plates (Figure S1 in Supplementary Materials). As in our earlier studies, after modifying the bacterial DNA with a selected antibiotic and digesting it with the Fpg protein, the highest level of damage was observed for the strains R4 $>$ R2 $>$ R3 $>$ K12. These values were twice as high for the respective pyridine derivatives as compared to the antibiotics used on bacterial DNA in all analyzed strains, especially in the R4 strain (Figure S3 in the Supplementary Materials). Therefore, in our methods of innovative syntheses, we are looking for compounds with a similar structure to antibiotics, but with much stronger biological and chemical properties, which will be more toxic to the analyzed bacterial cells [45-55], (Table 1).

In bacterial DNA isolated from the R4 strain, digested with modified pyridine derivatives, and appropriate antibiotics digested with the Fpg protein, a disappearance of the "ccc" form was observed, along with the appearance of a single-strand migration, similar to the "oc" form, which formed a complex with high molecular weight (see Figures S2 and S3 in Supplementary Materials). The effect of the separation and migration of bands in both experiments was very similar, and confirms that selected pyridine derivatives will replace commonly used antibiotics in the future, enhancing their biological functions by affecting the bacterial cell membrane. This is suggested by the results of digestion with the Fpg protein (Supplementary Materials Figures S2 and S3), which forms a strong complex in the form of visible concatamers after modification of bacterial DNA. The resulting complex is 
very stable in terms of electrophoresis. This suggests a covalent linkage of the Fpg protein and the DNA through appropriate amino acids or high-molecular-weight protein fragments, as well as the resulting DNA damage after modification with pyridine derivatives and antibiotics [45-55].

In previous work, a similar mechanism of action was described for the Fpg protein [45-50]. The analyzed model E. coli strains, including the particularly sensitive R4 strain, showed greater sensitivity than the R2 and R3 strains, as they had the longest LPS (Figures S1-S3 in the Supplementary Materials). Toxicity studies of the synthesis of new compounds and their effect on bacterial cells will allow for the better selection of substituents, leading to the creation of modern drugs with ideal biological parameters and microbial activity for the analyzed bacterial cells.

\section{Conclusions}

A new enzymatic method of target pyridine derivatives, which eliminates the application of toxic catalysts, was developed. For the first time, the promiscuous activity of lipases was shown in a multicomponent reaction, leading to the highly functionalized bioactive 2-amino-4-aryl-3,5-dicarbonitrile-6-sulfanylpyridines in organic solvent. The presented protocol offers several advantages, such as operational simplicity, environmental sustainability, easy work-up procedure, and high yields of the target products (53-91\%). The toxic effect of the obtained pyridine derivatives was evaluated on model E. coli strains. The analyzed pyridine derivatives are able to modify all E. coli model strains (R2-R4) and their bacterial DNA, changing the spatial structure of the LPS contained in their cell membranes. Among the derivatives studied, the compounds $\mathbf{5 b}, \mathbf{5 e}, \mathbf{5} \mathbf{f}$ and $\mathbf{5 j}$ were the most active. The activity of the tested compounds 5 strongly depends on the structure of the $\mathrm{R}_{2}$ substituent of the thiol unit (Figure 2). It was also noted that the change in the bromine atom in the aromatic ring to chlorine significantly reduced the activity of the compound $5 \mathrm{~g}$. Therefore, the studies will be continued in our laboratory to determine the influence of the $R_{2}$ unit structure of pyridine derivatives on their antibacterial activity. The toxicity of the aromatic groups in the analyzed pyridine derivatives, along with the alkyl substituents in the $\mathrm{R}_{1}$ and $R_{2}$ positions, probably depends on their interaction with the membrane, which may be involved in the destruction of the cell walls by changing their hydrophobicity. Changes in the permeability and integrity of the bacterial membrane may result in a specific bacterial response to biologically active compounds, e.g., the antibiotics used. The damage of plasmid DNA bases, which is especially visible after digestion with Fpg protein, was associated with alkylation and oxidative modifications induced by pyridine derivatives. This may suggest that the presence of these compounds has a toxic effect on bacterial LPS, generating strong oxidative stress, as was observed in our previous studies [45-52]. The results of the presented research are important for understanding the biological properties of tested pyridine derivatives as a function of potential new antibiotics and their toxic effects on Gram-negative bacteria in the face of the growing drug-resistance pandemic. This can be seen in our previous works, related to the characteristics of the model E. coli K12 and R2-R4 [44-51]. Finally, the analyzed pyridine derivatives are more cytotoxic in the model bacterial cells than the most commonly used antibiotics: kanamycin, streptomycin, ciprofloxacin, bleomycin and cloxacillin.

Supplementary Materials: The following are available online at https:/ / www.mdpi.com/article/10 $.3390 / \mathrm{ma14185401/s1}$, Figure S1. Examples of MIC and MBC on microplates with different concentration of studied compounds $\left(\mathrm{mg} \mathrm{L}^{-1}\right)$. Figure S2. An example of an agarose gel electrophoresis separation of isolated plasmids DNA from R4 strains modified with selected pirymidine derivatives. Figure S3. An example of an agarose gel electrophoresis separation of isolated plasmids DNA from R4 strains modified with antibiotics: kanamycine, streptomycine, cloxacilline, ciprofloxaclinie, bleomycine digested (or not) with repair enzymes Fpg. 
Author Contributions: Conception or design of the work, P.K., methodology, P.K., D.K., P.S., A.H., K.K., Ł.L., M.L., R.L., M.S., J.M., K.G. synthesis of all compound, P.K., D.K., R.O., P.S., A.H.; software, P.K., R.L.; M.S.; validation, P.K., R.L.; R.O., D.K., J.M., K.G.; formal analysis, P.K., D.K., R.O.; investigation, P.K., D.K., P.Ś., A.H., Ł.L., M.L., R.O., K.G., K.K.; interpretation of data for the work, P.K., R.O.: drafting the work, P.K., R.O. revising it critically for important intellectual content; P.K.; R.O.; K.K., D.K. resources, P.K.; R.O., K.K.; data curation, P.K., D.K., original draft preparation, P.K., R.O. review and editing, P.K.; visualization, P.K., D.K., M.S., supervision, P.K., R.O. project administration, P.K., R.O. funding acquisition K.K. All authors have read and agreed to the published version of the manuscript.

Funding: This work was supported by grant Medical University of Białystok SUB/2DN/21/001/2201 and by National Science Center, Poland project OPUS No. 2019/33/B/ST4/01118.

Institutional Review Board Statement: Not applicable.

Informed Consent Statement: Not applicable.

Data Availability Statement: On request of those interested.

Acknowledgments: The authors thank Jolanta Łukasiewicz from Ludwik Hirszfeld Institute of Immunology and Experimental Therapy (Polish Academy of Sciences) for providing the strains of E. coli.

Conflicts of Interest: The authors declare no conflict of interest.

\begin{abstract}
Abbreviations
MIC - minimum inhibitory concentration, MBC - minimum bactericidal concentration, ocopen circle, ccc-covalently closed circle.
\end{abstract}

\title{
References
}

1. May, B.C.H.; Zorn, J.A.; Witkop, J.; Sherrill, J.; Wallace, A.C.; Legname, G.; Prusiner, S.B.; Cohen, F.E. Structure-Activity Relationship Study of Prion Inhibition by 2-Aminopyridine-3,5-dicarbonitrile-Based Compounds: Parallel Synthesis, Bioactivity, and in Vitro Pharmacokinetics. J. Med. Chem. 2007, 50, 65-73. [CrossRef]

2. Perrier, V.; Wallace, A.C.; Kaneko, K.; Safar, J.; Prusiner, S.B.; Cohen, F.E. Mimicking Dominant Negative Inhibition of Prion Replication through Structure-Based Drug Design. Proc. Natl. Acad. Sci. USA 2000, 97, 6073-6078. [CrossRef] [PubMed]

3. Meibom, D.; Albrecht-Küpper, B.; Diedrichs, N.; Hübsch, W.; Kast, R.; Krämer, T.; Krenz, U.; Lerchen, H.-G.; Mittendorf, J.; Nell, P.G.; et al. Neladenoson Bialanate Hydrochloride: A Prodrug of a Partial Adenosine A1Receptor Agonist for the Chronic Treatment of Heart Diseases. Chem. Med. Chem. 2017, 12, 728-737. [CrossRef] [PubMed]

4. Beukers, M.W.; Chang, L.C.W.; Künzel, J.K.V.F.D.; Mulder-Krieger, T.; Spanjersberg, R.F.; Brussee, A.J.; Ijzerman, A.P. New, Non-Adenosine, High-Potency Agonists for the Human Adenosine A2BReceptor with an Improved Selectivity Profile Compared to the Reference AgonistN-Ethylcarboxamidoadenosine. J. Med. Chem. 2004, 47, 3707-3709. [CrossRef]

5. Cadilla, R.; Turnbull, P. Selective Androgen Receptor Modulators in Drug Discovery: Medicinal Chemistry and Therapeutic Potential. Curr. Top. Med. Chem. 2006, 6, 245-270. [CrossRef] [PubMed]

6. Zhang, F.; Wang, G. A review of non-nucleoside anti-hepatitis B virus agents. Eur. J. Med. Chem. 2014, 75, 267-281. [CrossRef] [PubMed]

7. Reddy, T.R.K.; Mutter, R.; Heal, W.; Guo, K.; Gillet, V.J.; Pratt, S.; Chen, B. Library Design, Synthesis, and Screening: Pyridine Dicarbonitriles as Potential Prion Disease Therapeutics. J. Med. Chem. 2006, 49, 607-615. [CrossRef]

8. Guo, K.; Mutter, R.; Heal, W.; Reddy, T.R.; Cope, H.; Pratt, S.; Thompson, M.J.; Chen, B. Synthesis and evaluation of a focused library of pyridine dicarbonitriles against prion disease. Eur. J. Med. Chem. 2008, 43, 93-106. [CrossRef]

9. Sun, D.; Zhu, L.; Yao, D.; Chen, L.; Fu, L.; Ouyang, L. Recent progress in potential anti-hepatitis B virus agents: Structural and pharmacological perspectives. Eur. J. Med. Chem. 2018, 147, 205-217. [CrossRef] [PubMed]

10. Mamaghani, M.; Tabatabaeian, K.; Bayat, M.; Nia, R.H.; Rassa, M. Regioselective Synthesis and Antibacterial Evaluation of a New Class of Substituted Pyrazolo[3,4-b] Pyridines. J. Chem. Res. 2013, 37, 494-498. [CrossRef]

11. Anderson, D.R.; Hegde, S.; Reinhard, E.; Gomez, L.; Vernier, W.F.; Lee, L.; Liu, S.; Sambandam, A.; Snider, P.A.; Masih, L. Aminocyanopyridine inhibitors of mitogen activated protein kinase-activated protein kinase 2 (MK-2). Bioorganic Med. Chem. Lett. 2005, 15, 1587-1590. [CrossRef] [PubMed]

12. Zhang, X.; Qiu, Y.; Li, X.; Bhattacharjee, S.; Woods, M.; Kraft, P.; Lundeen, S.G.; Sui, Z. Discovery and structure-activity relationships of a novel series of benzopyran-based KATP openers for urge urinary incontinence. Bioorganic Med. Chem. 2009, 17, 855-866. [CrossRef] 
13. Samadi, A.; Marco-Contelles, J.; Soriano, E.; Álvarez-Pérez, M.; Chioua, M.; Romero, A.; González-Lafuente, L.; Gandía, L.; Roda, J.M.; López, M.G.; et al. Multipotent drugs with cholinergic and neuroprotective properties for the treatment of Alzheimer and neuronal vascular diseases. I. Synthesis, biological assessment, and molecular modeling of simple and readily available 2-aminopyridine-, and 2-chloropyridine-3,5-dicarbonitriles. Bioorganic Med. Chem. 2010, 18, 5861-5872. [CrossRef]

14. Evdokimov, N.M.; Kireev, A.S.; Yakovenko, A.A.; Antipin, M.Y.; Magedov, I.V.; Kornienko, A. One-Step Synthesis of Heterocyclic Privileged Medicinal Scaffolds by a Multicomponent Reaction of Malononitrile with Aldehydes and Thiols. J. Org. Chem. 2007, 72, 3443-3453. [CrossRef] [PubMed]

15. Kantam, M.L.; Mahendar, K.; Bhargava, S.K. One-pot, three-component synthesis of highly substituted pyridines and 1,4dihydropyridines by using nanocrystalline magnesium oxide. J. Chem. Sci. 2010, 122, 63-69. [CrossRef]

16. Singh, K.N.S.A.S.K.; Singh, S.K. Microwave-assisted, one-pot multicomponent synthesis of highly substituted pyridines of medicinal utility using KF/alumina. ARKIVOC 2009, 2009, 153-160. [CrossRef]

17. Mamgain, R.; Singh, R.; Rawat, D.S. DBU-catalyzed three-component one-pot synthesis of highly functionalized pyridines in aqueous ethanol. J. Heterocycl. Chem. 2009, 46, 69-73. [CrossRef]

18. Khan, N.; Choudhury, L.H.; Pal, S.; Parvin, T. A simple and efficient method for the facile access of highly functionalized pyridines and their fluorescence property studies. RSC Adv. 2012, 2, 12305-12314. [CrossRef]

19. Shinde, P.V.; Shingate, B.B.; Shingare, M.S. Aqueous Suspension of Basic Alumina: An Efficient Catalytic System for the Synthesis of Poly Functionalized Pyridines. Bull. Korean Chem. Soc. 2011, 32, 459-462. [CrossRef]

20. Koszelewski, D.; Brodzka, A.; Madej, A.; Trzepizur, D.; Ostaszewski, R. Evaluation of gem-Diacetates as Alternative Reagents for Enzymatic Regio- and Stereoselective Acylation of Alcohols. J. Org. Chem. 2021, 86, 6331-6342. [CrossRef]

21. Madej, A.; Koszelewski, D.; Paprocki, D.; Brodzka, A.; Ostaszewski, R. The amine as carbonyl precursor in the chemoenzymatic synthesis of Passerini adducts in aqueous medium. Catal. Commun. 2020, 145, 106118. [CrossRef]

22. Paprocki, D.; Koszelewski, D.; Madej, A.; Brodzka, A.; Walde, P.; Ostaszewski, R. Evaluation of Biodegradable Glucose Based Surfactants as a Promoting Medium for the Synthesis of Peptidomimetics with the Coumarin Scaffold. ChemistrySelect 2020, 5, 9607-9614. [CrossRef]

23. Paprocki, D.; Madej, A.; Koszelewski, D.; Brodzka, A.; Ostaszewski, R. Multicomponent Reactions Accelerated by Aqueous Micelles. Front. Chem. 2018, 6, 502. [CrossRef]

24. Chavan, A.S.; Kharat, A.S.; Bhosle, M.R.; Mane, R.A. A convenient Baker yeast accelerated, one-pot synthesis of pentasubstituted thiopyridines. Synth. Commun. 2017, 47, 1777-1782. [CrossRef]

25. Kęciek, A.; Paprocki, D.; Koszelewski, D.; Ostaszewski, R. Evaluation of alcohols as substrates for the synthesis of 3,4dihydropyrimidin-2(1H)-ones under environmentally friendly conditions. Catal. Commun. 2020, 135, 105887. [CrossRef]

26. Zaorska, E.; Gawryś-Kopczyńska, M.; Ostaszewski, R.; Ufnal, M.; Koszelewski, D. Evaluation of thionolactones as a new type of hydrogen sulfide (H2S) donors for a blood pressure regulation. Bioorganic Chem. 2021, 108, 104650. [CrossRef] [PubMed]

27. Truppo, M.D. Biocatalysis in the Pharmaceutical Industry: The Need for Speed. ACS Med. Chem. Lett. 2017, 8, 476-480. [CrossRef] [PubMed]

28. Dwivedee, B.P.; Soni, S.; Sharma, M.; Bhaumik, J.; Laha, J.K.; Banerjee, U.C. Promiscuity of Lipase-Catalyzed Reactions for Organic Synthesis: A Recent Update. ChemistrySelect 2018, 3, 2441-2466. [CrossRef]

29. Koszelewski, D.; Ostaszewski, R. Biocatalytic Promiscuity of Lipases in Carbon-Phosphorus Bond Formation. ChemCatChem 2019, 11, 2554-2558. [CrossRef]

30. Koszelewski, D.; Ostaszewski, R. Enzyme Promiscuity as a Remedy for the Common Problems with Knoevenagel Condensation. Chem.-A Eur. J. 2019, 25, 10156-10164. [CrossRef]

31. Albanese, D.C.M.; Gaggero, N. Albumin as a promiscuous biocatalyst in organic synthesis. RSC Adv. 2015, 5, 10588-10598. [CrossRef]

32. Safaei-Ghomi, J.; Ghasemzadeh, M.A. CuI nanoparticles: A highly active and easily recyclable catalyst for the synthesis of 2-amino-3,5-dicyano-6-sulfanyl pyridines. J. Sulfur Chem. 2012, 34, 233-241. [CrossRef]

33. Mishra, S.; Ghosh, R. K2CO3-Mediated, One-Pot, Multicomponent Synthesis of Medicinally Potent Pyridine and Chromeno[2,3b]pyridine Scaffolds. Synth. Commun. 2012, 42, 2229-2244. [CrossRef]

34. Kottawar, S.S.; Siddiqui, S.A.; Bhusare, S.R. Scandium triflate-catalyzed one-pot multi-component synthesis of 2-amino-6thiopyridine-3,5-dicarbonitriles. Heterocycl. Commun. 2012, 18, 249-252. [CrossRef]

35. Safaei-Ghomi, J.; Shahbazi-Alavi, H.; Heidari-Baghbahadorani, E. SnO nanoparticles as an efficient catalyst for the one-pot synthesis of chromeno[2,3-b]pyridines and 2-amino-3,5-dicyano-6-sulfanyl pyridines. RSC Adv. 2014, 4, 50668-50677. [CrossRef]

36. Thimmaiah, M.; Li, P.; Regati, S.; Chen, B.; Zhao, J.C.-G. Multi-component synthesis of 2-amino-6-(alkylthio)pyridine-3,5dicarbonitriles using $\mathrm{Zn}(\mathrm{II})$ and $\mathrm{Cd}(\mathrm{II})$ metal-organic frameworks (MOFs) under solvent-free conditions. Tetrahedron Lett. 2012, 53, 4870-4872. [CrossRef] [PubMed]

37. Allahi, A.; Akhlaghinia, B. WEB (water extract of banana): An efficient natural base for one-pot multi-component synthesis of 2-amino-3,5-dicarbonitrile-6-thio-pyridines. Phosphorus Sulfur Silicon Relat. Elements 2020, 196, 328-336. [CrossRef]

38. Rahmani, F.; Mohammadpoor-Baltork, I.; Khosropour, A.R.; Moghadam, M.; Tangestaninejad, S.; Mirkhani, V. Propylphosphonium hydrogen carbonate ionic liquid supported on nano-silica as a reusable catalyst for the efficient multicomponent synthesis of fully substituted pyridines and bis-pyridines. RSC Adv. 2015, 5, 39978-39991. [CrossRef] 
39. Safaei-Ghomi, J.; Tavazo, M.; Vakili, M.R.; Shahbazi-Alavi, H. Chitosan functionalized by citric acid: An efficient catalyst for onepot synthesis of 2,4-diamino-5H-[1]benzopyrano[2,3-b]pyridine-3-carbonitriles 5-(arylthio) or 5-[(arylmethyl)thio] substituted. J. Sulfur Chem. 2017, 38, 236-248. [CrossRef]

40. Kowalczyk, P.; Madej, A.; Paprocki, D.; Szymczak, M.; Ostaszewski, R. Coumarin Derivatives as New Toxic Compounds to Selected K12, R1-R4 E. coli Strains. Materials 2020, 13, 2499. [CrossRef]

41. Kowalczyk, P.; Trzepizur, D.; Szymczak, M.; Skiba, G.; Kramkowski, K.; Ostaszewski, R. 1,2-Diarylethanols-A New Class of Compounds That Are Toxic to E. coli K12, R2-R4 Strains. Materials 2021, 14, 1025. [CrossRef] [PubMed]

42. Kowalczyk, P.; Madej, A.; Szymczak, M.; Ostaszewski, R. $\alpha$-Amidoamids as New Replacements of Antibiotics-Research on the Chosen K12, R2-R4 E. coli Strains. Materials 2020, 13, 5169. [CrossRef]

43. Kowalczyk, P.; Borkowski, A.; Czerwonka, G.; Cłapa, T.; Cieśla, J.; Misiewicz, A.; Borowiec, M.; Szala, M. The microbial toxicity of quaternary ammonium ionic liquids is dependent on the type of lipopolysaccharide. J. Mol. Liq. 2018, 266, 540-547. [CrossRef]

44. Borkowski, A.; Kowalczyk, P.; Czerwonka, G.; Cieśla, J.; Cłapa, T.; Misiewicz, A.; Szala, M.; Drabik, M. Interaction of quaternary ammonium ionic liquids with bacterial membranes-Studies with Escherichia coli R1-R4-type lipopolysaccharides. J. Mol. Liq. 2017, 246, 282-289. [CrossRef]

45. Kowalczyk, P.; Gawdzik, B.; Trzepizur, D.; Szymczak, M.; Skiba, G.; Raj, S.; Kramkowski, K.; Lizut, R.; Ostaszewski, R. $\delta$-Lactones-A New Class of Compounds That Are Toxic to E. coli K12 and R2-R4 Strains. Materials 2021, 14, 2956. [CrossRef]

46. Amor, K.; Heinrichs, D.E.; Frirdich, E.; Ziebell, K.; Johnson, R.P.; Whitfield, C. Distribution of Core Oligosaccharide Types in Lipopolysaccharides from Escherichia coli. Infect. Immun. 2000, 68, 1116-1124. [CrossRef]

47. Maciejewska, A.; Kaszowska, M.; Jachymek, W.; Lugowski, C.; Lukasiewicz, J. Lipopolysaccharide-linked Enterobacterial

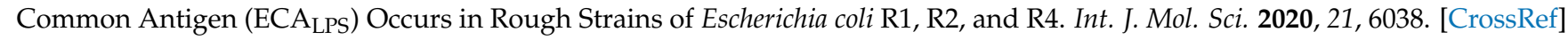
[PubMed]

48. Prost, M.E.; Prost, R. Basic parameters of evaluation of the effectiveness of antibiotic therapy. OphthaTherapy 2017, 4, 233-236. [CrossRef]

49. Pimenta, R.S.; Silva, F.L.; Silva, J.F.; Morais, P.B.; Braga, D.T.; Rosa, C.A.; Corrêa, A., Jr. Biological control of Penicillium italicum, P. digitatum and P. expansum by the predacious yeast Saccharomycopsis schoenii on oranges. Braz. J. Microbiol. 2008, 39, 85-90. [CrossRef]

50. Wink, D.A.; Laval, J. The Fpg protein, a DNA repair enzyme, is inhibited by the biomediator nitric oxide in vitro and in vivo. Carcinogenesis 1994, 15, 2125-2129. [CrossRef] [PubMed]

51. Møller, P.; Jantzen, K.; Løhr, M.; Andersen, M.H.G.; Jensen, D.M.; Roursgaard, M.; Danielsen, P.H.; Jensen, A.; Loft, S. Searching for assay controls for the Fpg- and hOGG1-modified comet assay. Mutagenesis 2017, 33, 9-19. [CrossRef] [PubMed]

52. Dang, W.; Tong, C.; Yang, Y.; Liu, Y.; Liu, B.; Zhou, H.; Wang, W. A cascade amplification platform assisted with DNAzyme for activity analysis, kinetic study and effector screening of Fpg in vitro. Analyst 2019, 144, 1731-1740. [CrossRef] [PubMed]

53. Antoci, V.; Cucu, D.; Zbancioc, G.; Moldoveanu, C.; Mangalagiu, V.; Amariucai-Mantu, D.; Aricu, A.; Mangalagiu, V. Bis(imidazole/benzimidazole)-pyridine derivatives: Synthesis, structure and antimycobacterial activity. Futur. Med. Chem. 2020, 12, 207-222. [CrossRef] [PubMed]

54. Eryılmaz, S.; Çelikoğlu, E.T.; Idil, Ö.; Inkaya, E.; Kozak, Z.; Mısır, E.; Gül, M. Derivatives of pyridine and thiazole hybrid: Synthesis, DFT, biological evaluation via antimicrobial and DNA cleavage activity. Bioorganic Chem. 2019, 95, 103476. [CrossRef] [PubMed]

55. Sun, B.; Dong, Y.; Lei, K.; Wang, J.; Zhao, L.; Liu, M. Design, synthesis and biological evaluation of amide-pyridine derivatives as novel dual-target (SE, CYP51) antifungal inhibitors. Bioorganic Med. Chem. 2019, 27, 2427-2437. [CrossRef] [PubMed] 